Article

\title{
The Geography of Knowledge Sourcing, Personal Networks, and Innovation Effects: Evidence from the Biomedical Firms in Guangzhou, China
}

\author{
Jili Xu@, Fiona Fan Yang and Desheng Xue * \\ School of Geography and Planning, Sun Yat-Sen University, Guangzhou 510275, China; \\ xujili@mail2.sysu.edu.cn (J.X.); yangfan25@mail.sysu.edu.cn (F.F.Y.) \\ * Correspondence: eesxds@mail.sysu.edu.cn; Tel.: +86-20-8411-2738
}

Received: 11 May 2019; Accepted: 19 June 2019; Published: 21 June 2019

check for updates

\begin{abstract}
Personal networks, in contrast to organizational relations, have recently increased their significance to firms by allowing them to acquire external knowledge and strengthen their innovation capacity. Hot debates on the geography and innovation effects of personal networks persist, but these discussions are mainly derived from research works on western economies. Since personal interactions are context-sensitive, this paper examines the geography and the innovation effects of personal networks on biomedical firms in Guangzhou, which has a unique political and socioeconomic context owing to the transitional nature of China. This case study indicates that the geographic nature of personal knowledge networks is largely locally-based, and the primary driver of such networks is experience-based practices, such as repeated face-to-face contacts, labor mobility, and shared life experience. Personal knowledge networks contribute to both problem-solving and radical innovation for firms as a result of the guanxi-based relations in China that transform personal networks into channels for mobilizing innovation-related resources. Moreover, by dividing personal networks into bonding, bridging, and linking networks, this paper also de-homogenizes personal networks and delineates specific and differentiated innovation effects of manifold social relationships. Based on the research findings, policy implications aiming at laying the social ground of innovation are addressed.
\end{abstract}

Keywords: knowledge sourcing; personal networks; social capital; innovation; biotechnology; Guangzhou

\section{Introduction}

In the era of knowledge-based economy, knowledge has become a strategic economic resource and learning has been a key process for innovation [1]. Accordingly, product competitiveness of firms has hinged more upon novel knowledge input than cost reduction [2,3]. Since the 2000s, with increasing complexities in the nature of innovation, shortened product life cycles, and a deepened division of labor, novel knowledge, to a larger extent, has depended on the combination of knowledge from various professional fields possessed by heterogenous actors [4,5]. The internal knowledge pool of firms has consequently been insufficient to generate novelty, and acquiring external knowledge therefore has been greatly emphasized and labelled as "open innovation" [6,7].

Networks that link firms with universities, research institutes, and intermediary agencies are considered to be key conduits of knowledge sourcing, which has recently extended from interorganizational linkages into interpersonal ties [8-10]. Initially, much work has been focused on the characteristics of interorganizational networks, such as geographical distribution [11,12], formation dynamics [13], and innovation effects [14]. Over the past two decades, along with a new wave of technological advances in individual-based mobile communication and the lower cost of 
long-distance transport, individuals rather than organizations have played an increasingly significant role in knowledge sourcing and innovation $[15,16]$. In the so-called "knowledge economy $2.0^{\prime}$, learning is conceptualized as a process of social interactions among knowledgeable individuals taking place in a social-cultural context that goes beyond organizations [17]. In light of this trend, there has been more weight placed on the importance of personal networks for knowledge sourcing and innovation for firms $[18,19]$. Despite the significance acknowledged recently, the geography of personal networks and how they contribute to knowledge sourcing and innovation of firms are still underexplored, particularly in developing countries where socioeconomic context varies substantially from that of western economies [20,21].

China, which has been recently labeled a "new star" on the global technological ladder, enjoys a unique political and socioeconomic context in contrast to its western counterparts [22,23]. Studying the geography and innovation effects of personal networks of firm representatives in Chinese cities may lead to some distinct observations. Moreover, as China has been rapidly evolving from a rural-based acquaintance society into a modern urban society through urbanization at an unprecedented pace over the past four decades [24], personal networks in this country may be "hybrid entities" that exert heterogeneous effects on firm innovation. First, the mass of migrants pouring into cities may still tend to retain their social networks in the previous limited "circle of acquaintances", and universal trust among strangers in cities can hardly be built in the short term $[25,26]$. Second, with economic reform in a gradual manner, market cooperation and career-based professional associations may start to play an increasingly significant role in narrowing interpersonal distances [24,27].

With respect to the business type, emerging high-technology firms, in particular, have become increasingly dependent on external personal networks [28]. On the one hand, in these emerging industries, technology and market changes are occurring much faster than the publication of research achievements (e.g., journal articles, scientific reports, patents), and only through interpersonal interactions can firm managers keep pace with continuously updated opportunities and tacit knowledge (e.g., know-who) [29,30]. On the other hand, emerging high-technology firms are often characterized by a knowledge-intensive and trans-disciplinary nature [31]. Fostering such environments requires a combination of diverse and interrelated cutting-edge knowledge and skills that highly rely upon knowledge accumulation stemming from certain long-term and trusted personal networks [32].

Therefore, this paper sees the academic value of adopting a typology of personal networks to examine the geography of personal networks and the innovation effects on emerging biomedical firms in Guangzhou, China. Riding on such a unique and understudied case, this article aims to enrich the existing scholarly efforts on personal knowledge networks and firm innovation and also reveal scientific evidence to boost innovation-driven sustainable urban development by new sectors with growth potential. In the following sections, a theoretical background about the geography of personal networks for knowledge sourcing and innovation, together with a typology of personal networks, is explained. Section 3 introduces the study area and the research design. Empirical results are illustrated in Section 4. In the last two sections, we discuss the results in a broader context and conclude the study.

\section{Theoretical Context}

\subsection{Geography of Personal Networks for Knowledge Sourcing and Innovation of Firms}

Since the nature of the innovation process is becoming more interactive, open, and complicated, the external knowledge sourcing activities of firms often vary with regard to knowledge channels and geographical distribution [33,34]. Tödtling et al. (2006) and Trippl et al. (2009) proposed different types of knowledge channels, including market links, formal cooperation, informal networks, and spillovers [35,36]. Different channels, as a result, are characterized by differentiated geographical natures. For example, the "local buzz-global pipeline" model put forward by Bathelt et al. (2004) stresses the roles of spontaneous local informal contacts and deliberate global formal collaborations [37]. 
Personal networks, in contrast to organizational relations, are often recognized as comprising informal contacts and spillovers and have been viewed as locally-based and context-sensitive $[29,38]$. More recently, however, this dichotomized classification has been criticized for its rigidity and oversimplicity [36]. On the one hand, we have witnessed increasing global business travel, leading to the flourishing "global buzz" or "temporary clusters", such as international trade fairs and academic conferences [39,40]. Personal networks for learning and mobilizing knowledge, as it is argued, can easily go beyond the "local fix", thus benefiting from relational proximity and "communities of practice" [41,42]. On the other hand, personal networks are not restricted to spontaneous informal contacts but can also be planned to be embedded in formal relationships, which are governed by contracts and developed through repeated reciprocal business collaborations in the long run [43]. As Hess (2004) highlighted, "The literature on embeddedness stresses the central role of concrete personal relations and networks of relations to generate trust. Societal embeddedness also reflects the business systems idea of an institutional and regulatory framework that affects and in part determines an actor's behavior" [44]. Therefore, it is widely acknowledged that the geography of personal knowledge networks, which increasingly take place in relational space, is not locally confined but globally extended $[45,46]$.

The geography of personal knowledge networks in Chinese cities may be distinguished from that of its western counterparts. First, technological development in China in many fields is still lagging behind that in developed countries, and social interactions among Chinese professionals at the global scale may not be as productive as those of the westerners who have been highly embedded in global production networks $[47,48]$. Second, high-tech industrial development in China has been advanced by the central government since the mid-2000s and is promoted through top-down industrial plans [49]. Consequently, vicious intercity competition for resources from upper levels, local protectionism, and redundant construction have resulted in weak horizontal relations and less effective external social interactions between cities [50,51]. Because of the specific political and socioeconomic context in China, personal networks for knowledge sourcing and innovation may be more locally based and context-sensitive. Here, the first hypothesis is formulated.

Hypothesis 1. The geography of external personal networks for knowledge sourcing of high-tech firms in Chinese cities is still locally oriented.

In regard to innovation effects, it is argued that the personal knowledge networks of firms contribute more to incremental innovation than radical innovation [52]. Although there is now a broad consensus on the increasing importance of external networks for firm innovation, personal networks may still reside in a relatively marginal position $[35,36]$. It is argued that compared with market links and R\&D alliances, external personal networks may play a less crucial role in radical innovation [53]. Chen (2009) highlighted that personal knowledge networks may be effective for incremental innovation, but they are not pivotal to radical innovation [52]. Through a detailed study on R\&D workers in information and communication technology (ICT) sectors in Cambridge, Huber (2013) indicated that external personal knowledge networks play an important role in firm innovation since they enable $R \& D$ workers to keep up with the latest technological development, yet these networks are less prominent in radical innovation and problem-solving processes [19].

Nevertheless, the arguments made by western scholars may somewhat underestimate the innovation effects of personal knowledge networks, especially when shifted to the Chinese context. With the transitional nature of the political and socioeconomic context in China, the legal environment and market mechanisms are still being perfected [24]. At the same time, the unprecedented rapid urbanization in a relatively short time does not necessarily translate to the collapse of the traditional rural society in which people depend on the trust of a limited range of acquaintances [25]. Guanxi still performs as a significant organizing force in Chinese society [27,54]. According to Fei et al. (1992), "Guanxi is strictly personal in the sense that the specific prescribed actions needed to maintain the link 
are based on norms of reciprocity and are defined as personal obligations on the part of each individual, particularly the subordinate in the dyadic relationship" [55]. Due to the lack of a strong rule of law in China historically, interpersonal guanxi functions as a supplementary means of resource exchange and configuration for the long term, which endows personal networks in China with more subtle meanings. Two remarkable aspects should be distinguished from the western world for firm innovation. First, apart from being merely functioned as knowledge and learning channels based on common competencies and cognitive proximity [56,57], personal networks in China may act as exchange mechanisms for acquiring innovation-related resources that contribute to new breakthroughs [26]. Second, unlike the rule- and goal-based organizations in the western countries, personal networks in China may even somehow transcend organizational interests because of the private facet and dyadic sense that support mutual interests, which can thereby resolve concrete problem-solving issues [55,58]. Therefore, the second hypothesis is based on the innovation effects of personal networks for firms in China.

Hypothesis 2. External personal networks can achieve radical innovation as well as solve specific problems for firms in Chinese cities.

\subsection{How Personal Networks Contribute to Innovation Processes: A Typology of Personal Networks}

Though many studies have reached a broad consensus on the significance of personal networks for innovation $[13,17,19,21,32]$, scarce work has paid attention to how personal networks contribute to innovation. As mentioned above, China has undergone rapid urbanization and shifted from a rural-based society toward a modern society in a startlingly short period of time. Chinese cities are characterized by hybrid interpersonal networks, including family- and relative-based ties, modern professional relations, and weak contacts, for knowledge sourcing and innovation [26,27]. Therefore, when it comes to exploring the impact of personal network processes in China on firm innovation, a more nuanced subdivision and the corresponding innovation effects become essential. Previously, networks for sourcing knowledge and innovation appeared to be only roughly divided into traded and untraded, formal and informal, static and dynamic, and personal and organizational [19,36,59]. Attempts to further split personal networks into different forms to examine the multifarious innovation effects are rare.

Establishing a typology of personal networks by referring to the social capital theory and the multiplicity of social ties may provide a subtler picture for examining knowledge sourcing and innovation effects for firms [32,60]. Woolcock (2004) delineated a typology that accounts for three types of social networks: bonding social capital, bridging social capital, and linking social capital. Bonding social capital includes immediate family, friends, and neighbors; bridging social capital includes more distant colleagues and associates; and linking social capital refers to connections to people in positions of authority [61]. Revisiting the multiplexity of social ties [62,63], Grabher and Ibert (2006) outlined multiple personal networks with communality, sociability, and connectivity [32]. Communality denotes robust and thick ties that are firmly rooted in personal familiarity and social coherence. Relations are based on mutual experiences and common history [64]. The notion of sociality emphasizes ephemeral yet intense networking. Sociality is primarily driven by long-term professional motivations but unfolds in private forms of interaction and casual encounters [65]. The concept of connectivity denotes the socially thinnest, most culturally neutral, and, in a sense, the weakest embedded fashion of networking [66,67]. It is argued that communality amalgamates friendship and professional issues, whereas sociality more strategically supports business agendas with private facets, and communication in connectivity is relatively distant from personal realms and most succinctly focuses on the specific subject matter of a present project [32].

Therefore, with the research work on the heterogeneity within personal networks, this paper attempts to de-homogenize the external personal networks of firms and separate them into bonding, 
bridging, and linking networks to investigate the differentiated innovation effects. Hypothesis 3 is thus formed as follows.

Hypothesis 3. Different types of external personal networks of firms in Chinese cities have heterogeneous innovation effects.

\section{Study Area and Research Design}

\subsection{Study Area}

Since the mid-2000s, particularly in the aftermath of the global financial crisis, China has experienced a dramatic rise in $R \& D$ inputs and the number of domestic high-tech firms $[68,69]$. The Chinese central government designated seven "Strategic emerging industries" (e.g., biotechnology, new materials, and new energy resources, etc.) that are knowledge- and technology-intensive to foster indigenous innovation capacity [50]. National central cities, such as Beijing, Shanghai, Guangzhou, and Shenzhen, are deemed innovation centers because of a powerful economic base, an agglomeration of science and technology resources, and preferential policies [70]. Guangzhou, the largest city and one of the national innovation hubs in southern China, has been one of the designated National Biological Industrial Bases since 2006 [71]. Biotechnology and its applications, especially in the pharmaceutical and medical treatment fields, has been proactively fostered by multilevel governments and emerged as one of the most significant high-tech industries in Guangzhou [72,73]. The Guangzhou High-tech Zone, in particular, has been specified by the state as the geographical carrier for innovation-oriented biomedical firms. According to the Development Plan of the Biomedical and Health industry in Guangzhou Development Zone (2016-2020), there were more than 500 firms in the biomedical and health fields in the zone in 2015, with an output value of 36.8 billion yuan.

\subsection{Research Design}

To better indicate the role of Chinese social ties, we chose indigenous small-and-medium sized firms, which rely more on external personal networks for innovation-related inputs as research objects. By considering both availability and coverage ratio, 39 respondent firms, nearly $8 \%$ of the sum total, were picked as representatives to carry out the empirical study. Therefore, the research data used in this study were derived from semi-structured and in-depth interviews with 44 representatives (e.g., entrepreneurs and senior managers in charge of R\&D, marketing, or decision-making) of 39 investigated firms in the biotechnology, biopharmaceutical, and biomedical fields located in Guangzhou Science City and Guangzhou International Biotech Island which are the core areas of Guangzhou High-tech Zone. Some firms have more than one respondent covering entrepreneurs and heads of different departments, which provides a wider scope of personal networks of firms since entrepreneurs and senior managers at key job positions can contribute to firm innovation by mobilizing respective social resources $[19,26]$. Thus, the combination of personal networks of representatives belonging to the same firm is regarded as the personal networks of firms. Interviews were conducted from October 2017 to January 2018 and focused on asking firm representatives to recall social relationships external to their firms that provided R\&D or business support to new product development in their firms over the past five years. For each social network, representatives were asked to offer relevant information about the contact, such as his/her work unit (e.g., university, research institute, hospital, firm in the biomedical fields, firm outside of the biomedical fields), place of residence (e.g., in Guangzhou, in other Chinese cities, overseas), type of social relationships (e.g., family member, relative, classmate, teacher, former colleague, former boss, partner developed from business collaborations, acquaintance based on business affairs), the specific knowledge they exchanged, and the impacts on technology or product development. Each interview averagely lasted around 70 minutes. All interviews were conducted in Chinese and recorded with transcription. The transcripts with around 800,000 Chinese characters constitute the text database for the analysis of evidence. Following the research aim, 
we comprehensively reviewed and classified the text database, and cited typical cases to demonstrate the research findings. Apart from the first-hand survey, second-hand materials, such as portal websites, company directories, and brochures, also provided invaluable supplementary information.

The different types of personal networks are elaborated before presenting the empirical parts of the study. By combining the social capital theory [60,61] and multiplicity of social ties of firm representatives $[32,63]$ with the operational nature of biomedical firms in the Chinese context, this study developed a typology of personal networks (Figure 1). First, "bonding personal networks" refers to private social relations that are deeply rooted in common experiences with strong social embeddedness; the individuals that form bonding personal networks include family members, relatives, and middle school or university schoolmates [62]. Second, "bridging personal networks" refers to professional associated, career-oriented, and strategic relations that unfold in private forms of interactions and casual encounters with medium social embeddedness, ranging from teachers, former bosses, former colleagues, and project members to business partners with social proximity [27]. Third, "linking personal networks" refers to the socially thinnest, culturally neutral, and specific matter-oriented relations with low social embeddedness, for example, people within the same online technical communities and acquaintances known through professional meetings or trade fairs $[66,74]$. Subsequently, the geography of knowledge sourcing, knowledge functions, and innovation effects of three types of personal networks for biomedical firms in Guangzhou are then examined, respectively.

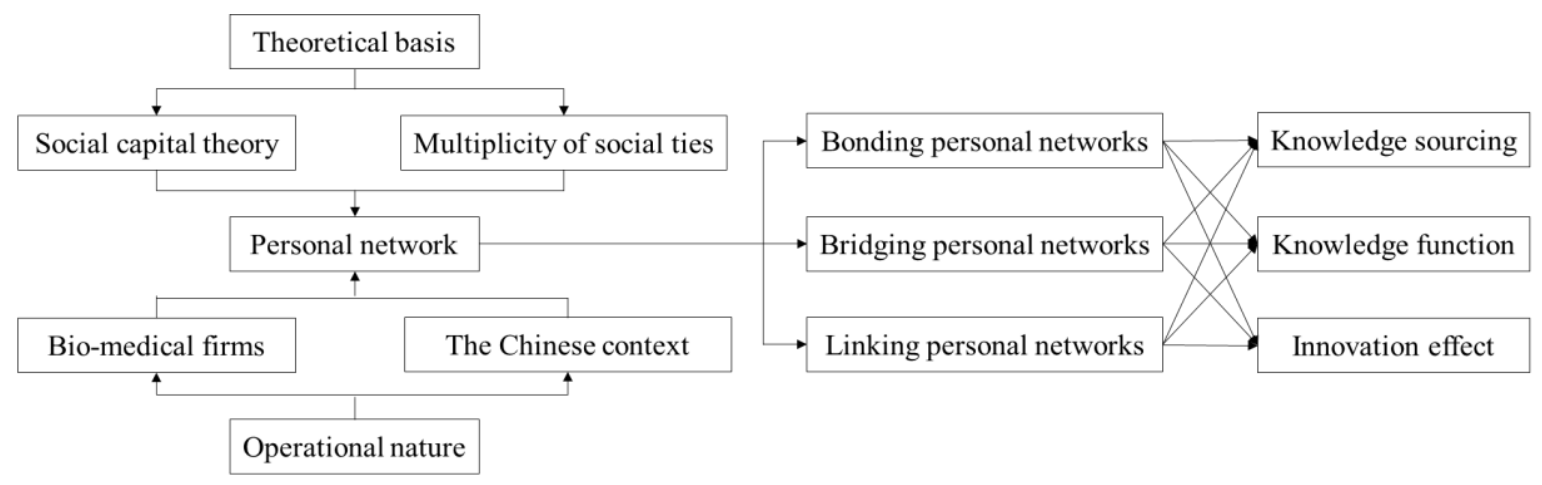

Figure 1. Research framework.

\section{Results}

\subsection{The Geography of Knowledge Sourcing through Personal Networks}

Based on interviews with 44 firm representatives, 541 beneficial social relationships in total are recalled by them, including 247 (45.9\%) at the local level, 232 (43.1\%) at the national level, and $59(11.0 \%)$ at the global level. The number of local social relationships is in excess of the aggregated links with other cities in China and even three times more than that with global actors. Therefore, it is obvious that personal networks for sourcing knowledge in Guangzhou are highly locally based. In particular, distant personal networks that transcend the national boundary do not emerge as important dynamics for knowledge sourcing. These patterns vary among empirical findings in western economies [14,45].

With respect to different types of personal networks, 127 bonding personal networks (23.5\%), 385 bridging personal networks (71.1\%), and 29 linking personal networks (5.4\%) are evident (Table 1 ). From the overall structure, bridging personal networks have played a dominant role in sourcing external knowledge for firms; at the same time, bonding personal networks still serve as nonnegligible sources of knowledge sharing. In sharp contrast, linking personal networks have barely stabilized through public activities and are of minor importance, at least quantitatively. It is apparent that the professional association and career orientation have already become key mechanisms that govern knowledge sourcing for biomedical firms in Guangzhou. However, the moderate number of bonding personal networks suggests that personal networks continue to be hybrid in nature in transitional 
China. Due to a limited degree of universal trust between strangers, "temporary clusters" such as the trade fairs and exhibitions $(39,74)$, have made a minor contribution to forming external personal knowledge networks.

Investigating the geography of different types of personal knowledge networks should offer a more nuanced picture of the various distance- and context-related sensitivities among them. Generally, they are all similarly concentrated at the local level. An interesting detail lies in the observation that it is only the bridging personal networks that can, to some extent, climb to the global scale, resulting in 49 beneficial relations, which is remarkably more than the other two types of relations. It is suggested that social ties formed on a professional basis are most conducive to overcoming geographical distance and institutional and cultural barriers; this notion is highly consistent with existing findings $[75,76]$. For example, a firm manager put it, "I was attracted by the 'talent programme' which provides abundant subsidies and tax incentives to overseas returnees. Since science transcends national boundaries, I am still able to keep in touch with my doctoral supervisor overseas through our professional associations" (Personal interview with a R\&D manager, 6 December 2017). Furthermore, from our fieldwork, trust-based interpersonal networks for sourcing knowledge are primarily formed through experience-based practices, such as repeated face-to-face contacts, labor mobility, and shared life experience, all of which render networking a locally prominent activity. For instance, a firm manager expressed, "Guangzhou is such a mega city filled with many job opportunities, I have changed my jobs several times but I never think of leaving this city due to sunk cost and familiarity. Through switching companies, I have gained more work experience and local social resources especially the ties with former colleagues" (Personal interview with a market manager, 6 November 2017). As a result, Hypothesis 1 "The geography of the external personal networks for knowledge sourcing of high-tech firms in Chinese cities is still locally oriented" is accepted.

Table 1. The geography of knowledge sourcing through personal networks.

\begin{tabular}{|c|c|c|c|c|}
\hline $\begin{array}{c}\text { Type of Personal } \\
\text { Network }\end{array}$ & $\begin{array}{c}\text { Number of } \\
\text { Relations of Each } \\
\text { Network Type }\end{array}$ & $\begin{array}{l}\text { Percentage } \\
(\%)\end{array}$ & $\begin{array}{l}\text { Geographical } \\
\text { Scale }\end{array}$ & $\begin{array}{c}\text { Number of Relations at Each } \\
\text { Geographical Scale }\end{array}$ \\
\hline \multirow{3}{*}{$\begin{array}{l}\text { Bonding personal } \\
\text { network }\end{array}$} & \multirow{3}{*}{127} & \multirow{3}{*}{23.5} & Local & 59 \\
\hline & & & National & 58 \\
\hline & & & Global & 10 \\
\hline \multirow{3}{*}{$\begin{array}{l}\text { Bridging personal } \\
\text { network }\end{array}$} & \multirow{3}{*}{385} & \multirow{3}{*}{71.1} & Local & 175 \\
\hline & & & National & 161 \\
\hline & & & Global & 49 \\
\hline \multirow{3}{*}{$\begin{array}{l}\text { Linking personal } \\
\text { network }\end{array}$} & \multirow{3}{*}{29} & \multirow{3}{*}{5.4} & Local & 13 \\
\hline & & & National & 13 \\
\hline & & & Global & 3 \\
\hline
\end{tabular}

\subsection{How Personal Networks Contribute to Innovation Effects}

\subsubsection{Bonding Personal Networks}

(1) Share Up-to-Date Generic Knowledge and Quasi-Public Information

Since bonding personal networks are formed primarily on the basis of common experiences, personal familiarity, and strong social embeddedness, a high degree of trust functions as the major governance mechanism of these relations [32]. The nature of bonding personal networks leads to low communication costs and adequate exchange of knowledge. Despite this, the specific knowledge that is conducive to technological innovation and product exploitation through this channel is rarely accessed because of the diversification of biotechnology-related professional fields and the corresponding wide cognitive gap existing between them $[57,77]$. As a manager put it, "Since we have known each other for a long time throughout our lives, we are private friends more than just school peers. Since our graduation, however, we have been employed by different enterprises carrying out research work in distinct sub-directions. So, it is more appropriate for us to talk about the new trends of the biotechnology industry, newly-released policies, 
and big events rather than specific technical issues or firm strategies" (Personal interview with an R\&D manager, 24 November 2017).

In the meantime, apart from general knowledge, communication channels in bonding personal relationships play a critical role in the exchange of quasi-public information, including competitors' conditions and potential collaborators. Thanks to reciprocity and interpersonal trust, quasi-public information can be efficiently circulated through personal bonding networks among a limited number of interrelated contacts. Particularly in China, where a perfect legal system and adequate market mechanisms have not yet been developed, bonding personal networks act as compensational means to obtain quasi-public information to better realize external environmental change [27]. "Long-term, stable social relationships are my treasure", a general manager said, "only through these kinds of social ties can we exchange some confidential information and never worry about damaging our own interests. I can get informed about the product strategies and market profile of rivals from a small sphere of old friends, which helps us possess abundant information to adapt to external change more effectively (Personal interview with a general manager, 16 November 2017).

\section{(2) Mobilize R\&D- and Market-Related Resources}

Bonding personal networks are nevertheless restricted in the realm of interactive learning; more importantly, they instead act as crucial pipelines for acquiring complementary resources [78]. In China, where guanxi plays a crucial role in socioeconomic activities [54,55], long-term, stable, and reciprocity-based personal relationships are seen as grounded guanxi for mobilizing career-related resources. This kind of solid guanxi is normally built around common experiences, shared values, and mutual respect, all of which are highly embedded in bonding personal networks. The majority of newly established biomedical firms may lack some high-cost R\&D equipment or market access channels, and bonding personal networks may help to ensure the successful operation of their innovation and business activities. As an R\&D manager put it, "I got my doctoral degree in Guangzhou several years ago, and most of my schoolmates have been working here since graduation. We have known each other for many years since school days, and there is no need to go out to have a drink to keep in touch. Instead, once you need help, give them a call. For me, sometimes I need to share their experimental facilities to do some test with low frequency, and purchasing one is obviously not profitable for me. On the other hand, I would not worry about data security issues by sharing their equipment" (Personal interview with an R\&D manager, 1 December 2017).

\section{(3) Stimulate Entrepreneurship}

Innovation in high-tech industries highly depends on the type of entrepreneurship that is characterized by risk-taking, spin-offs, and social responsibility $[79,80]$. We find that bonding personal networks of the entrepreneurs and senior managers in the surveyed firms not only form resource channels but also stimulate entrepreneurship. For example, bonding personal networks appear to become a kind of psychological capital that gives entrepreneurs and senior managers a sense of belonging and self-identity in this industry. Since, in transitional China, industrial policies and technological regimes are continuously changing [48], bonding social networks that are stable and predictable have become a reliable mechanism for firm managers to embrace risks to exploit new products and expand markets. Thus, bonding personal networks appear to play a critical role in complementing the imperfect legal framework and coping with the rapidly changing institutional environment. An entrepreneur expressed, "I am not afraid of exploiting new clinical drugs because of these schoolmates and private friends I have in this industry. They always encourage me to strive for potential trials and show their confidence in me, which to a great extent stimulates me to deal with uncertainties. More importantly, it is with no doubt that if I encounter any challenges beyond those expected, they will with no doubt provide me constructive advice and solid support immediately" (Personal interview with a co-founder and general manager, 24 October 2017). 


\subsubsection{Bridging Personal Networks}

(1) Introduce Advanced Technologies and Management Modes

As a developing country, China's technological development still lags behind the developed world, particularly in newly emerging industries [72,81]. Therefore, bridging personal networks have become effective ways to learn from professionals in advanced economies $[27,54]$. Specifically, we find that bridging personal networks are conducive to the formation of socially embedded collaborative R\&D, strategic alliances, and market links between biomedical firms in Guangzhou and technologically related firms in advanced countries. These bridging personal networks are mainly formed by studying abroad with doctoral supervisors, working with a former boss in foreign countries, and engaging in state-led project collaborations [49]. Labor mobility across national boundaries, of course, would not interrupt these tight, career-based, and interest-motivated communities [82]. As an entrepreneur illustrated, "I obtained my Bachelor's degree in Guangzhou and then pursued my doctoral degree in Switzerland. I have been working for my doctoral supervisor's enterprise for several years since graduation. More recently, I was attracted by the Talent Program initiated by the state to return to China to start my own business with the key technological invents I focused on in Switzerland. My doctoral advisor authorizes the key technology to us, permitting us to apply for patents domestically. As we are able to master and develop this key technology by ourselves so that my company enjoys a competitive advantage in this professional field nationwide" (Personal interview with an entrepreneur, 20 December 2017). Labor mobility can be bidirectional: in addition to returning from abroad, domestic talents going abroad can also achieve such cooperation. For example, "Our company has been in strategic collaboration with the University of Toronto since 2004. Our new products have been included in their quality appraised system, which ensures the strict monitoring of our product quality through their international leading technologies," a manager said. "The research group leader of the University of Toronto is a Chinese professor, who is a former colleague of my boss. They both appreciate each other in professional attainments and share common values, keeping a close mutual respect all the time" (Personal interview with an R\&D general manager, 6 January 2018).

Also, some bridging personal networks can be formed through state-led international collaboration projects, such as the Sino-British Biotechnology Bridge and China-Israel Biological Industry Incubation Base. Although some firms expressed that they could rarely obtain the know-how of the technologies from foreign partners, they had benefited a lot from their advanced business management and organizational routines. As an R\&D manager said, "Our relationship with a French company is built through the funding of the Sino-British Biotechnology Bridge. Through this cooperation, leading groups of both companies keep intense contact and build mutual trust. We appreciate that they not only provide advanced technologies, but also, equally important, make us benefit more from their management system and business routine. Gradually we selectively absorb these practices into our own rules to make our company more effectively operated" (Personal interview with an R\&D manager, 24 November 2017).

\section{(2) Solve Specific Technical Problems}

Bridging personal networks, which are formed by sharing a common professional ground and career motivation, include not only relations characterized by a hierarchical technological gap, such as teacher-student and leader-subordinate, but also social ties with horizontal technological complementarities, such as former colleagues and former project members [32,55]. Former colleagues who worked for the same research or market group enjoy high cognitive proximity as well as private friendship [56,57]. Hence, even though they may jump to other firms, they can still communicate regarding specific technical issues without formidable cognitive barriers and privacy concerns, which is labelled as "gone but not forgotten" [83]. In this way, bridging personal networks appear to ensure valuable external support and advice in the process of innovation [32]. Some managers may have such connections with colleagues in other technologically-related firms, universities, or research institutes. As an R\&D manager reported, "I worked in a biotechnology firm in Shenzhen before I changed to my present firm in Guangzhou in 2012. Former colleagues in the same technical group and I keep close contact. Some of 
them may have also left Shenzhen to Shanghai or Beijing, but we still talk about specific technical issues as well as private life through WeChat. Once I come up against uncertainties or problems in RED processes, I tend to seek advice from them. Due to a high degree of mutual trust and technical relatedness, it is unnecessary for me to introduce much about the relevant knowledge for helping them to understand my circumstances. And you never worry about information leakage" (Personal interview with an R\&D general manager, 24 November 2017).

It should be noted that a vast majority of entrepreneurs and senior managers of biomedical firms have social ties to domestic universities and research institutes. Some firms are university spin-offs, and the founders of such firms who are scientists may hold key technological discoveries [36,59]. Hence, they would likely make full use of bridging social networks with professors in universities and research institutes in order to realize product exploitation on the basis of their discoveries. By optimizing development directions and consolidating scientific principles, professors may become firm advisers who are involved in product development. As a founder put it, "I am now still an adjunct professor at Jinan University in Guangzhou, whilst my focus is on transforming scientific discoveries to new products. This tough process cannot be realized without enormous help from my former colleagues in local and other domestic universities. They always provide me the scientific frontiers that keep modifying our commercialization directions. At times we still need face-to-face contacts to deal with specific technical issues" (Personal interview with an entrepreneur, 24 October 2017). From the evidence above, Hypothesis 2 "External personal networks can achieve radical innovation as well as solve specific problems for firms in Chinese cities" is accepted.

(3) Demand-Driven New Product Development

Customers have become increasingly crucial in today's innovation process by providing feedback to producers and generating heterogeneous demands [84]. In developing countries such as China, where there is a huge potential market for high-technology products, short-term market-based innovation is more achievable than upgrading to cutting-edge technologies [48,53]. Bridging personal networks, which are partly based on business cooperation that draw on complementarities in value creation, play a significant role in obtaining key feedback from customers, particularly professional users in the biomedical fields [37,84]. Some of the investigated firms, especially those in the medical equipment field, vigorously depend on professional feedback from doctors in major hospitals to develop new products to adapt their novel requirements. As an R\&D director said, "Most of our firm leaders graduated from Sun Yat-Sen College of Medical Science, so we keep intimate relations with our teachers, who are professors as well as chief doctors in university-affiliated hospitals. They provide us invaluable feedback about issues of current medical equipment they encounter during practical work, which to a large extent reflects true market demands. We exploit new products on the basis of these ideas after preliminary feasibility analysis. Until now, three provincial-level research projects have been approved in this manner. Equally important, we can also keep accumulating knowledge and improving our technologies by carrying out these projects" (Personal interview with an R\&D director, 28 December 2017).

\subsubsection{Linking Personal Networks}

(1) Knowledge Exchange and Problem-Solving

Characterized by the lowest level of social embeddedness and a lack of mutual trust, linking personal networks are mainly formed by pure knowledge exchange and professional reciprocity [32,69]. To this end, when building linking personal networks, the Internet offers the advantages of low-cost communication, a semi-anonymous identity, and easily accessed information [69]. For managers in biomedical firms, online technical forums and various professional groups accessible through social apps are essential channels to exchange knowledge and expand personal social networks. Communications through these conduits are mostly knowledge- and technology-oriented without much concern for social norms and emotional burdens, which, in turn, is a situation that is conducive to effective learning and problem-solving. As put by one R\&D manager, "I knew an acquaintance through a biotechnology communication group on $Q Q$. He works as an RED manager in a medical technology firm in 
Suzhou. Though we have not yet met in person, we appreciate each other. As long as I encounter problems, he always proactively helps me and shares much of his knowledge and practical experience with me, benefiting me a lot in my RED work. Over a certain period, mutual trust between us has gradually formed through repeated interactions and positive feedback" (Personal interview with an R\&D general manager, 26 October 2017).

(2) Expand Potential Collaborations

Local "buzz", including workshops, policy briefings, and training sessions organized by public actors, serves as an effective way for managers to expand linking personal networks, primarily at local and regional levels [29,72]. These institutional arrangements, which aim to facilitate interpersonal contacts and social resource sharing in China, have become principal dynamics for building social networks in addition to private networks. As a consequence of the imperfection of intellectual property protection and the legal environment in transitional China, public sectors affiliated with the government promote the formation of networks with strangers [72]. That is to say, the state plays a crucial role in linking up relational assets, but the process is primarily confined to a geographical area because of interjurisdictional competition and local protectionism [51,69]. Managers may substantially depend on local buzz to acquire "know-who" knowledge and enlarge potential social resource pools (i.e., relations waiting to be activated when necessary). As a manager pointed out, "Workshops organized by the management committee of the Guangzhou International Biotech Island or Guangzhou Development Zone provide an excellent platform for us to know indigenous policies and enterprises. These activities may not directly contribute to our business but they tell us who can I seek for cooperation in RED or market accessibility, which is invaluable for us" (Personal interview with an R\&D manager, 29 December 2017).

\section{(3) Grasp Innovation Opportunities}

Another way to expand linking personal networks is to attend "temporary clusters" such as public activities, including trade fairs, exhibitions, and academic conferences [39,74]. Professionals come together for a short time and engage in intensive face-to-face contact with other professionals to acquire the latest trends in knowledge, science, and technology. Talks with strangers tend to involve a great deal of novel information and knowledge injected from other related fields, since weak ties can connect individuals possessing a different knowledge stock $[67,85]$. Therefore, managers proactively engage in these talks and build linking personal networks, albeit with limited access to stable and trustful relationships. At the very least, linking personal networks built through these public activities provide much room for individuals to grasp newly emerged innovation opportunities. "I place great value on academic conferences", a general manager highlighted, "every section manager of my firm is required to attend academic conferences in relation to their professional fields. On the one hand, being open to scientific advancements and learning novel knowledge grounds our own RED. On the other hand, more significantly, with explicit purposes in our mind, cooperating with experts in specific fields related to ours plays a key role in successful product development" (Personal interview with a general manager, 13 December 2017).

To wrap up, dividing personal networks into different subtypes, in contrast to taking them as a whole, provides us with a more nuanced image of knowledge functions and innovation effects for biomedical firms in Guangzhou within the transitional political and socioeconomic context (Table 2). Personal networks, however, should not be merely regarded as opportunities for informal learning or social contacts, as they can also be embedded in formal interfirm networks and used as a channel to form guanxi in China and mobilize innovation-related resources [26,55]. Furthermore, different forms of personal networks classified by different degrees of social embeddedness exert distinct but not mutually exclusive influences on firm innovation. Therefore, Hypothesis 3 "Different types of external personal networks of firms in Chinese cities have heterogeneous innovation effects" is validated. Moreover, with respect to heterogeneous knowledge functions and innovation effects, it should be noted that each type of personal network is irreplaceable: individuals acquire quasi-public information and stimulate entrepreneurship through bonding personal networks, introduce new technology and 
firm management through bridging personal networks, and expand the pool of potential collaborators through linking personal networks.

Table 2. A typology of personal networks for knowledge sourcing and innovation effects.

\begin{tabular}{cccc}
\hline Type of Network & $\begin{array}{c}\text { Bonding Personal } \\
\text { Network }\end{array}$ & $\begin{array}{c}\text { Bridging Personal } \\
\text { Network }\end{array}$ & $\begin{array}{c}\text { Linking Personal } \\
\text { Network }\end{array}$ \\
\hline $\begin{array}{c}\text { Geography of } \\
\text { knowledge sourcing }\end{array}$ & $\begin{array}{c}\text { Locally-concentrated; } \\
\text { Nationally-pervasive }\end{array}$ & $\begin{array}{c}\text { Locally-concentrated; } \\
\text { Nationally-pervasive; } \\
\text { Globally-connected }\end{array}$ & $\begin{array}{c}\text { Locally-concentrated; } \\
\text { Nationally-connected }\end{array}$ \\
\hline Knowledge function & Exploration & $\begin{array}{c}\text { Exploration; } \\
\text { Problem-solving }\end{array}$ & $\begin{array}{c}\text { Exploration; } \\
\text { Problem-solving }\end{array}$ \\
\hline Innovation effect & Incremental innovation & $\begin{array}{c}\text { Incremental innovation; } \\
\text { Radical innovation }\end{array}$ & Incremental innovation \\
\hline
\end{tabular}

\section{Discussion}

Underpinned by advancing individual-based communication technologies, lower long-distance travel cost, and the rising significance of professional talents for innovation, personal networks as a type of channel for firms to source knowledge and stimulate innovation have gained considerable weight among scholars as well as policy-makers $[17,19,36]$. There are expanding research works on the geography and innovation effects of personal networks which are mostly derived from the western world; a case study in transitional China will provide intriguing and distinct observations [42,43].

In regarding to the geography of personal networks for knowledge sourcing, there still exist hot debates on whether they can go beyond the "local fix" [37,41]. In the early 2000s, a "local buzz-global pipeline" model was proposed to highlight the distance-sensitive and context-dependent personal interactions, resulting in localized phenomena $[4,29,37]$. Later on, an increasing number of studies criticized the simplified dichotomy of local personal ties and global organizational networks [36,45]. Faulconbridge (2006) argued that social interactions are capable of stretching into global spaces in globalized organizations (e.g., globally operated advertising firms), since these social practices focus on reproducing rather than transferring knowledge, which can better overcome institutional and cognitive barriers [41]. Moreover, business travel-induced "global buzz" and "temporary clusters", like trade fairs, exhibitions, and academic conferences, also lay robust grounds for distant personal networks, since established social ties are not easily disrupted by talent mobility $[39,40]$. Recently, more literature has highlighted that personal networks can link actors across various geographical scales for knowledge sourcing and firm innovation $[17,45]$. However, this paper reveals that personal networks of biomedical firms in Guangzhou for sourcing knowledge are still locally concentrated. "Global buzz" and "temporary clusters" still make minor contribution to the formation of geographically distant social ties. This differentiation between China and its western counterparts can be attributed to technological gaps, institutional variations, and the different level of universal trust $[5,24,26]$.

Studies on the innovation effects of external personal networks for firms, moreover, have been placing great emphasis on knowledge exploration and incremental innovation instead of problem-solving and radical innovation [19,52]. In the western world, the formation of personal networks for knowledge sourcing and firm innovation highly rests with cognitive proximity [57,77], absorptive capacity [56], and competence complementarity [31]. In addition, due to a sound legal environment and stable business rules, interpersonal interactions must comply with organizational interests, such as confidentiality protection and market competition, and thus function more as a channel for interactive learning and idea exchange [16,67]. As a result, personal networks are more functioned as vehicles for knowledge exploration (e.g., brainstorming and exchanging up-to-date trends) and incremental innovation there [28]. In a sharp contrast, personal networks in China enjoy particularities due to long-term cultural roots in guanxi-based traditional society $[25,27,54]$. This paper has some interesting findings that personal networks of biomedical firms in Guangzhou function more 
as channels for acquiring innovation-oriented resources and sharing risks than as mere interactive learning mechanisms. Meanwhile, the dyadic nature of guanxi-based interpersonal ties, can somehow transcend the organizational interests to discuss concrete technical issues in a limited range of absolutely trusted relationships [55]. Hence, it is confirmed that personal networks for firms in China play a substantial role in problem-solving and radical innovation.

Though existing studies have acknowledged positive effects of personal networks for knowledge sourcing and firm innovation, rare work has probed into how personal networks contribute to innovation processes. Moreover, it should be noted that personal networks would not be seen as homogenous entities when examining their impacts on innovation processes of firms in China. The transitional context of China is characterized by economic reforms in a gradual manner and rapid urbanization at an unprecedented pace, personal networks retain traditional "acquaintance-based" strong ties on the one hand, and are also newly built through professional communities and "weak ties" on the other $[24,26]$. A subdivision of personal networks by referring to the social capital theory and the multiplicity of social ties may offer a more nuanced picture in China $[32,61,66]$.

\section{Conclusions}

By contextualizing the personal networks of high-tech firms in Chinese cities and drawing on existing theoretical works, this paper examines the geography of personal networks for knowledge sourcing and how they contribute to firm innovation.

The geography of personal networks of biomedical firms for sourcing knowledge and stimulating innovation in Guangzhou is still locally oriented to a large extent. The number of beneficial social relationships with actors in other Chinese cities is much lower than that within Guangzhou. Global personal ties for knowledge sourcing and firm innovation are almost absent. The geographical distribution of personal networks of biomedical firms in Guangzhou is shaped by the transitional nature of China which is deviated from the western economies. First, since China adopts a gradual reform process towards marketization, hierarchal command economy still plays a part in incubating emerging high-tech industries $[50,68]$. A lack of interjurisdictional linkages, redundant construction, and vicious competition, to some extent, restrict the extension of beneficial personal networks beyond administrative boundaries [51]. Second, an imperfect legal environment and a modern society of strangers formed by rapid urbanization can hardly elevate the degree of universal trust in the short term [26]. It leads to the fact that individuals rely more on repeated face-to-face contacts and common life experience to build trust, which is highly sensitive to geographical distance. Third, existing technological gaps between China and developed countries in emerging high-tech fields such as the biomedical sector inhibit firm representatives from absorbing more advanced knowledge from other countries or overseas regions. It is indicated that most of personal knowledge networks at the global level are propelled by labor mobility (e.g. attracting overseas returnees and domestic experts moving outwards).

It is revealed that personal networks of biomedical firms in Guangzhou contribute not only to knowledge exploration and incremental innovation, but also to problem-solving and radical innovation. Personal knowledge networks in China, which is remarkably distinct from western countries in nature, should not be viewed as a mere learning catalyst but more as a mechanism for mobilizing innovation-related resources. Guanxi-based interpersonal ties are deeply rooted in the Chinese social-cultural context, which has functioned as a body of essential rules for governing knowledge sourcing and innovation processes. On one side, guanxi has acted as a channel for resource configuration to compensate for the imperfect legal and market environment in China historically $[25,27]$. It implies that individuals linked with personal ties can exchange and transfer needed innovation-related resources with regardless of cognitive proximity and absorptive capacity, thereby helping to bring about new breakthroughs $[26,58]$. On the other side, guanxi is dyadic in essence in that may transcend organizational interests to achieve mutual win-win results [55]. To this 
end, on the premise of absolute mutual trust, some concrete technical issues can also be communicated through strong ties, which supports problem-solving processes.

Due to the hybrid nature of personal networks in China, this paper attempts to de-homogenize personal networks to examine how they contribute to innovation processes of biomedical firms in Guangzhou. A typology of personal knowledge networks is proposed, including bonding, bridging, and linking personal networks. Different types of external personal networks indeed have heterogeneous knowledge functions and innovation effects. In terms of knowledge functions and innovation effects, bonding personal networks ensure knowledge exploration and incremental innovation; bridging personal networks facilitate knowledge exploration/problem-solving and incremental/radical innovation; and linking personal networks stimulate knowledge exploration/problem-solving and incremental innovation. It is also worth noting that each type of interpersonal relationship is irreplaceable in terms of its specific knowledge functions and innovation effects. For example, bonding personal networks lay the ground for stimulating entrepreneurship; bridging personal networks help to introduce advanced technologies and management patterns; and linking personal networks contribute to grasping potential innovation opportunities.

It is imperative to address policy implications on the basis of the research findings. First, social networks at the global level should be much strengthened to facilitate radical innovation. Localized learning is conducive to consolidating common knowledge base and building collective identity, but plays a minor role in radical innovation in contrast to global learning [12,15]. Guangzhou should aim at attracting overseas returnees from developed countries, organizing high-level international public activities, and encouraging international technological collaborations in related professional fields to get deeper involved in the global "epistemic community" [42]. Second, local government officials should take a greater part in building trust among strangers. A lack of social trust is the result of an imperfect legal and market environment in the long run, but progressive reforms will allow for a strong state in terms of resource configuration and public reputation [24,72]. Local government officials should move beyond the traditional "GDP-ism" logic towards bridging trusted linkages and "weak ties" between strangers to lay solid social ground for innovation [86]. Third, policies should be more open to dealing with interjurisdictional horizontal collaboration in forming wider professional communities. Limited social interactions out of Guangzhou are partly influenced by intercity competition and local protectionism [51]. To lift interactive efficiency and expand the contact scope, transportation, research funding, and employment should be better combined between different cities to expand professional communities in both geographical and knowledge areas.

Due to the limited accessibility to all biomedical firms in the Guangzhou High-tech Zone, we were merely able to interview 44 representatives of 39 (nearly $8 \%$ in sum) indigenous small-and-medium sized firms which rely more greatly on personal networks for sourcing external knowledge and stimulating innovation. Also, since this paper pays particular attention to how different types of personal networks impact innovation processes, qualitative approaches (e.g., face-to-face interview) were primarily adopted in order to unveil the evidence in detail, while quantitative methods were with regret not used here. By adopting a typology of personal networks, this paper has indeed revealed heterogenous knowledge functions and innovation effects of bonding, bridging, and linking personal networks on biomedical firms in Guangzhou. This preliminary attempt sheds lights on a batch of interesting points, such as different informal institutions on knowledge network subdivision and socio-spatial dynamics of firm innovation, calling for further and deeper scholarly efforts.

Author Contributions: D.X. conceived and designed the research; J.X. conducted this research, analyzed the data, and wrote the manuscript; F.F.Y. revised and reformatted the overall paper. All authors have read and approved the final manuscript.

Funding: This research was funded by the National Natural Science Foundation of China (No. 41320104001) and the Special Fund Project of the Basic Research Service of Sun Yat-Sen University (17lgjc04).

Acknowledgments: The authors are thankful to three anonymous reviewers for their helpful comments. We also appreciate Guan Jingwen and Huang Jian for their warm support in our fieldwork. 
Conflicts of Interest: The authors declare no conflict of interest.

\section{References}

1. Lundvall, B.; Johnson, B. The learning economy. J. Ind. Stud. 1994, 1, 23-42. [CrossRef]

2. OECD. The Knowledge-Based Economy; Science, Technology and Industry Outlook; OECD: Paris, France, 1996; pp. 229-256.

3. Crevoisier, O. The economic value of knowledge: Embodied in goods or embedded in cultures? Reg. Stud. 2016, 50, 189-201. [CrossRef]

4. Malmberg, A.; Maskell, P. Localized learning revisited. Growth Chang. 2006, 37, 1-18. [CrossRef]

5. Wang, C.C.; Lin, G.C.S. Geography of knowledge sourcing, heterogeneity of knowledge carriers and innovation of clustering firms: Evidence from China's software enterprises. Habitat Int. 2018, 71, 60-69. [CrossRef]

6. Manniche, J.; Moodysson, J.; Testa, S. Combinatorial knowledge bases: An integrative and dynamic approach to innovation studies. Econ. Geogr. 2017, 93, 480-499. [CrossRef]

7. Ettlinger, N. Open innovation and its discontents. Geoforum 2017, 80, 61-71. [CrossRef]

8. Cooke, P.; Morgan, K. The Associational Economy: Firms, Regions, and Innovation; Oxford University Press: Oxford, UK, 1998.

9. Yeung, H. Rethinking relational economic geography. Trans. Inst. Br. Geogr. 2005, 30, 37-51. [CrossRef]

10. Ter Wal, A.L.J.; Boschma, R.A. Applying social network analysis in economic geography: Framing some key analytic issues. Ann. Reg. Sci. 2009, 43, 739-756. [CrossRef]

11. Lorentzen, A. Knowledge networks in local and global space. Entrep. Reg. Dev. 2008, 20, 533-545. [CrossRef]

12. Gertler, M.; Levitte, Y. Local nodes in global networks: The geography of knowledge flows in biotechnology innovation. Ind. Innov. 2005, 12, 487-507. [CrossRef]

13. Martin, R. Differentiated knowledge bases and the nature of innovation networks. Eur. Plan. Stud. 2013, 21, 1418-1436. [CrossRef]

14. Moodysson, J. Principles and practices of knowledge creation: On the organization of "buzz" and "pipelines" in life science communities. Econ. Geogr. 2008, 84, 449-469. [CrossRef]

15. Amin, A.; Cohendet, P. Architectures of Knowledge, Firms, Capabilities and Communities; Oxford University Press: Oxford, UK, 2004.

16. Hassink, R.; Klaerding, C. The end of the learning region as we knew it: Towards learning in space. Reg. Stud. 2012, 46, 1055-1066. [CrossRef]

17. Rutten, R.; Boekema, F. From learning region to learning in a socio-spatial context. Reg. Stud. 2012, 46, 981-992. [CrossRef]

18. Dahl, M.; Pedersen, C. Knowledge flows through informal contacts in industrial clusters: Myth or reality? Res. Policy 2004, 33, 1673-1686. [CrossRef]

19. Huber, F. Knowledge-sourcing of R\&D workers in different job positions: Contextualising external personal knowledge networks. Res. Policy 2013, 42, 167-179. [CrossRef]

20. Aslesen, H.W.; Harirchi, G. The effect of local and global linkages on the innovativeness in ICT SMEs: Does location-specific context matter? Entrep. Reg. Dev. 2015, 27, 644-669. [CrossRef]

21. Fu, W.; Diez, J.; Schiller, D. Interactive learning, informal networks and innovation: Evidence from electronics firm survey in the Pearl River Delta, China. Res. Policy 2013, 42, 635-646. [CrossRef]

22. Crescenzi, R.; Rodriguez-Pose, A.; Storper, M. The territorial dynamics of innovation in China and India. J. Econ. Geogr. 2012, 12, 1055-1085. [CrossRef]

23. Wu, W.; Gaubatz, P. The Chinese City; Routledge: Abingdon, UK; New York, NY, USA, 2013.

24. Yeh, A.G.O.; Yang, F.F.; Wang, J. Economic transition and urban transformation of China: The interplay of the state and the market. Urban Stud. 2015, 52, 2822-2848. [CrossRef]

25. Fei, X. Rural Development in China: Prospect and Retrospect; University of Chicago Press: Chicago, IL, USA, 1989.

26. Bian, Y.; Qiu, H. The social capital of enterprises and its efficiency. Soc. Sci. China 2000, 2, 87-99. (In Chinese)

27. Yeung, H.W.C. Business networks and transnational corporations: A study of Hong Kong firms in the ASEAN region. Econ. Geogr. 1997, 73, 1-25. [CrossRef] 
28. Huber, F. On the role and interrelationship of spatial, social and cognitive proximity: Personal knowledge relationships of R\&D workers in the Cambridge information technology cluster. Reg. Stud. 2012, 46, 1169-1182. [CrossRef]

29. Storper, M.; Venables, A.J. Buzz: Face-to-face contact and the urban economy. J. Econ. Geogr. 2004, 4, 351-370. [CrossRef]

30. Sorenson, O. Social networks and industrial geography. J. Evol. Econ. 2003, 13, 513-527. [CrossRef]

31. Frenken, K.; van Oort, F.; Verburg, T. Relate variety, unrelated variety and regional economic growth. Reg. Stud. 2007, 41, 685-697. [CrossRef]

32. Grabher, G.; Ibert, O. Bad company? The ambiguity of personal knowledge networks. J. Econ. Geogr. 2006, 6, 251-271. [CrossRef]

33. Crevoisier, O.; Jeannerat, H. Territorial knowledge dynamics: From the proximity paradigm to multi-location milieus. Eur. Plan. Stud. 2009, 17, 1223-1241. [CrossRef]

34. Dahlander, L.; Gann, D.M. How open is innovation? Res. Policy 2010, 39, 699-709. [CrossRef]

35. Tödtling, F.; Lehner, P.; Trippl, M. Innovation in knowledge intensive industries: The nature and geography of knowledge links. Eur. Plan. Stud. 2006, 14, 1035-1058. [CrossRef]

36. Trippl, M.; Tödtling, F.; Lengauer, L. Knowledge sourcing beyond buzz and pipelines: Evidence from the Vienna software sector. Econ. Geogr. 2009, 85, 443-462. [CrossRef]

37. Bathelt, H.; Malmberg, A.; Maskell, P. Clusters and knowledge: Local buzz, global pipelines and the process of knowledge creation. Prog. Hum. Geogr. 2004, 28, 31-56. [CrossRef]

38. Asheim, T.; Coenen, L.; Vang, J. Face-to-face, buzz, and knowledge bases: Sociospatial implications for learning, innovation, and innovation policy. Environ. Plan. C Gov. Policy 2007, 25, 655-670. [CrossRef]

39. Torre, A. On the role played by temporary geographical proximity in knowledge transmission. Reg. Stud. 2008, 42, 869-889. [CrossRef]

40. Bathelt, H.; Schuldt, N. International trade fairs and global buzz, part I: Ecology of global buzz. Eur. Plan. Stud. 2010, 18, 1957-1974. [CrossRef]

41. Faulconbridge, J. Stretching tacit knowledge beyond a local fix? Global spaces of learning in advertising professional service firms. J. Econ. Geogr. 2006, 6, 517-540. [CrossRef]

42. Amin, A.; Roberts, J. Knowing in action: Beyond communities of practice. Res. Policy 2008, 37, $353-369$. [CrossRef]

43. Westlund, H.; Adam, F. Social capital and economic performance: A meta-analysis of 65 studies. Eur. Plan. Stud. 2010, 18, 893-919. [CrossRef]

44. Hess, M. 'Spatial' relationships? Towards a reconceptualization of embeddedness. Prog. Hum. Geogr. 2004, 28, 165-186. [CrossRef]

45. Fitjar, R.D.; Huber, F. Global pipelines for innovation: Insights from the case of Norway. J. Econ. Geogr. 2015, 15, 561-583. [CrossRef]

46. Jones, A. The rise of global work. Trans. Inst. Br. Geogr. 2008, 33, 12-26. [CrossRef]

47. Yeung, H.; Coe, N. Towards a dynamic theory of global production networks. Econ. Geogr. 2015, 91, $29-58$. [CrossRef]

48. Wei, Y.H.D.; Lu, Y.; Chen, W. Globalizing regional development in Sunan, China: Does Suzhou industrial park fit a Neo-Marshallian district model? Reg. Stud. 2009, 43, 409-427. [CrossRef]

49. Zhang, F.; Wu, F. "Fostering indigenous innovation capacities": The development of biotechnology in Shanghai's Zhangjiang high-tech park. Urban Geogr. 2012, 33, 728-755. [CrossRef]

50. Yang, C. Government policy change and evolution of regional innovation systems in China: Evidence from strategic emerging industries in Shenzhen. Environ. Plan. C Gov. Policy 2015, 33, 661-682. [CrossRef]

51. Xu, J.; Yeh, A.G.O. Interjurisdictional cooperation through bargaining: The case of the Guangzhou-Zhuhai railway in the Pearl river delta, China. China Q. 2013, 213, 130-151. [CrossRef]

52. Chen, L. Learning through informal local and global linkages: The case of Taiwan's machine tool industry. Res. Policy 2009, 38, 527-535. [CrossRef]

53. Hansen, T. Substitution or overlap? The relations between geographical and non-spatial proximity dimensions in collaborative innovation projects. Reg. Stud. 2015, 49, 1672-1684. [CrossRef]

54. Lin, G.C.S. Peri-urbanism in globalizing China: A study of new urbanism in Dongguan. Eurasian Geogr. Econ. 2006, 47, 28-53. [CrossRef] 
55. Fei, H.; Hamilton, G.; Wang, Z. From the Soil, the Foundations of Chinese Society: A Translation of Fei Xiaotong's Xiangtu Zhongguo; University of California Press: Berkeley, CA, USA, 1992.

56. Giuliani, E. The selective nature of knowledge networks in clusters: Evidence from the wine industry. J. Econ. Geogr. 2007, 7, 139-168. [CrossRef]

57. Nooteboom, B. Learning by interaction: Absorptive capacity, cognitive distance and governance. J. Manag. Gov. 2000, 4, 69-92. [CrossRef]

58. Fu, W.; Revilla Diez, J.; Schiller, D. Determinants of networking practices in the Chinese transition context: Empirical insights from the Pearl river delta. Tijdschr. Econ. Soc. Geogr. 2017, 108, 205-219. [CrossRef]

59. Storper, M. The Regional World: Territorial Development in a Global Economy; Guilford Press: New York, NY, USA, 1997.

60. Malecki, E.J. Regional social capital: Why it matters. Reg. Stud. 2012, 46, 1023-1039. [CrossRef]

61. Woolcock, M. Why and how planners should take social capital seriously. J. Am. Plan. Assoc. 2004, 70, 183-189.

62. Granovetter, M. Economic action and social structure: The problem of embeddedness. Am. J. Sociol. 1985, 91, 481-510. [CrossRef]

63. Uzzi, B. Social structure and competition in interfirm networks: The paradox of embeddedness. Adm. Sci. Q. 1997, 42, 35-67. [CrossRef]

64. Renninger, K.A.; Shumar, W. Building Virtual Communities: Learning and Change in Cyberspace; Cambridge University Press: Cambridge, UK, 2002.

65. Wittel, A. Toward a network sociality. Theory Cult. Soc. 2001, 18, 51-76. [CrossRef]

66. Grabher, G.; Ibert, O. Distance as asset? Knowledge collaboration in hybrid virtual communities. J. Econ. Geogr. 2014, 14, 97-123. [CrossRef]

67. Hauser, C.; Tappeiner, G.; Walde, J. The learning region: The impact of social capital and weak ties on innovation. Reg. Stud. 2007, 41, 75-88. [CrossRef]

68. Zhang, F. Building biotech in Shanghai: A perspective of regional innovation system. Eur. Plan. Stud. 2015, 23, 2062-2078. [CrossRef]

69. He, C.; Wang, J. Regional and sectoral differences in the spatial restructuring of Chinese manufacturing industries during the post-WTO period. GeoJournal 2012, 77, 361-381. [CrossRef]

70. Wei, Y.H.D.; Yuan, F.; Liao, H. Spatial mismatch and determinants of foreign and domestic information and communication technology firms in urban China. Prof. Geogr. 2013, 65, 247-264. [CrossRef]

71. $\mathrm{Xu}, \mathrm{J} . ;$ Yeh, A.G.O. City repositioning and competitiveness building in regional development: New development strategies in Guangzhou, China. Int. J. Urban Reg. Res. 2005, 29, 283-307. [CrossRef]

72. Bathelt, H.; Zhao, J. Conceptualizing multiple clusters in mega-city regions: The case of the biomedical industry in Beijing. Geoforum 2016, 75, 186-198. [CrossRef]

73. Wang, H.; Zhang, X.; Xiong, X.; Hu, Q.; Bing, H. Spatial agglomeration and changing trend of China's Bio-industry: Based on empirical data analysis of listed companies. Econ. Geogr. 2018, 38, 101-107. (In Chinese)

74. Maskell, P.; Bathelt, H.; Malmberg, A. Building global knowledge pipelines: The role of temporary clusters. Eur. Plan. Stud. 2006, 14, 997-1013. [CrossRef]

75. Asheim, B.T.; Gertler, M.S. Regional innovation systems and the geographical foundations of innovation. In The Oxford Handbook of Innovation; Fagerberg, J., Mowery, D.C., Nelson, R.R., Eds.; Oxford University Press: Oxford, UK, 2005; pp. 291-317.

76. Asheim, B.T.; Coenen, L. Knowledge bases and regional innovation systems: Comparing Nordic clusters. Res. Policy 2005, 34, 1173-1190. [CrossRef]

77. Boschma, R.A. Proximity and innovation: A critical assessment. Reg. Stud. 2005, 39, 61-74. [CrossRef]

78. Huber, F. Social capital of economic clusters: Towards a network-based conception of social resources. Tijdschr. Econ. Soc. Geogr. 2009, 100, 160-170. [CrossRef]

79. Iammarino, S.; McCann, P. The structure and evolution of industrial clusters: Transactions, technology and knowledge spillovers. Res. Policy 2006, 35, 1018-1036. [CrossRef]

80. Florida, R.; Adler, P.; Mellander, C. The city as innovation machine. Reg. Stud. 2017, 51, 86-96. [CrossRef]

81. Wang, C.C.; Lin, G.C.S. Dynamics of innovation in a globalizing china: Regional environment, inter-firm relations and firm attributes. J. Econ. Geogr. 2013, 13, 397-418. [CrossRef] 
82. Breschi, S.; Lissoni, F. Mobility of skilled workers and co-invention networks: An anatomy of localized knowledge flows. J. Econ. Geogr. 2009, 9, 439-468. [CrossRef]

83. Agrawal, A. Gone but not forgotten: Knowledge flows, labor mobility, and enduring social relationships. J. Econ. Geogr. 2006, 6, 571-591. [CrossRef]

84. Grabher, G.; Ibert, O.; Flohr, S. The neglected king: The customer in the new knowledge ecology of innovation. Econ. Geogr. 2008, 84, 253-280. [CrossRef]

85. Granovetter, M. The strength of weak ties. Am. J. Sociol. 1973, 78, 1360-1380. [CrossRef]

86. Wu, F. Planning centrality, market instruments: Governing Chinese urban transformation under state entrepreneurialism. Urban Stud. 2018, 55, 1383-1399. [CrossRef]

(C) 2019 by the authors. Licensee MDPI, Basel, Switzerland. This article is an open access article distributed under the terms and conditions of the Creative Commons Attribution (CC BY) license (http://creativecommons.org/licenses/by/4.0/). 